\title{
Otter distribution in Lithuania in 2008 and changes in the last decade
}

\author{
Laima Baltrūnaite ${ }^{\bowtie}$, Linas Balčiauskas, Raimundas Matulaitis, \\ and Vitalijus Stirké \\ Institute of Ecology of Vilnius University, Akademijos 2, LT-08412 Vilnius, Lithuania \\ $\bowtie$ Corresponding author, laima@ekoi.lt \\ Received 17 December 2008, revised 23 March 2009
}

\begin{abstract}
The distribution of Lutra lutra in Lithuania was studied in 2007-2008 by surveying spraints and other signs of its presence (so-called standard monitoring methods). In total, 745 sites were checked in various water bodies: rivers, lakes, reclamation ditches, fish farms, and artificial reservoirs. Out of them, 584 (78.4\%) were found positive. Fish farms were the most intensively used habitat - otters were found in all surveyed farms. Artificial reservoirs, medium-sized rivers, and streams were also frequently used. Within $100 \mathrm{~m}$ in the environs of a water body only anthropogenic landscape (towns, villages) was found to be a negative factor for otter presence. Other habitats both within $100 \mathrm{~m}$ in the environs and on the bank within $20 \mathrm{~m}$, as well as regulation of a water body, did not influence the presence of otters. It is concluded that the situation of otters in Lithuania is good. The population is widely distributed across the country and inhabits various water bodies.
\end{abstract}

Key words: Lutra lutra, distribution, habitat, Lithuania.

\section{INTRODUCTION}

The otter (Lutra lutra L.) is a protected species in Europe (Conroy \& Chanin, 2001). In Lithuania, the otter hunting is prohibited since 1975. In 1989 the species was included into the Red Data Book, category 4(I), and in 2000 it was downgraded to category $5(\mathrm{Rs})$ as a restored species.

The distribution of the otter in Lithuania was investigated at the beginning of the 1990s (Mickevičius, 1993; Baranauskas et al., 1994; Baranauskas \& Mickevičius, 1995a) and generalized in two editions of the Lithuanian mammal atlas (Balčiauskas et al., 1997, 1999). At that time the otter was a widespread and fairly common species in Lithuania (Fig. 1).

The average density was found to be $2-3$ individuals per $10 \mathrm{~km}$ of the riverbed (Ulevičius \& Balčiauskas, 1994). Positive localities known in 1999 included various rivers, lakes, and ponds. Otters were registered even in land reclamation ditches. The predator was most frequently found in fast-flowing medium-sized and small rivers with many hiding places on the shores, such as undermined roots of 


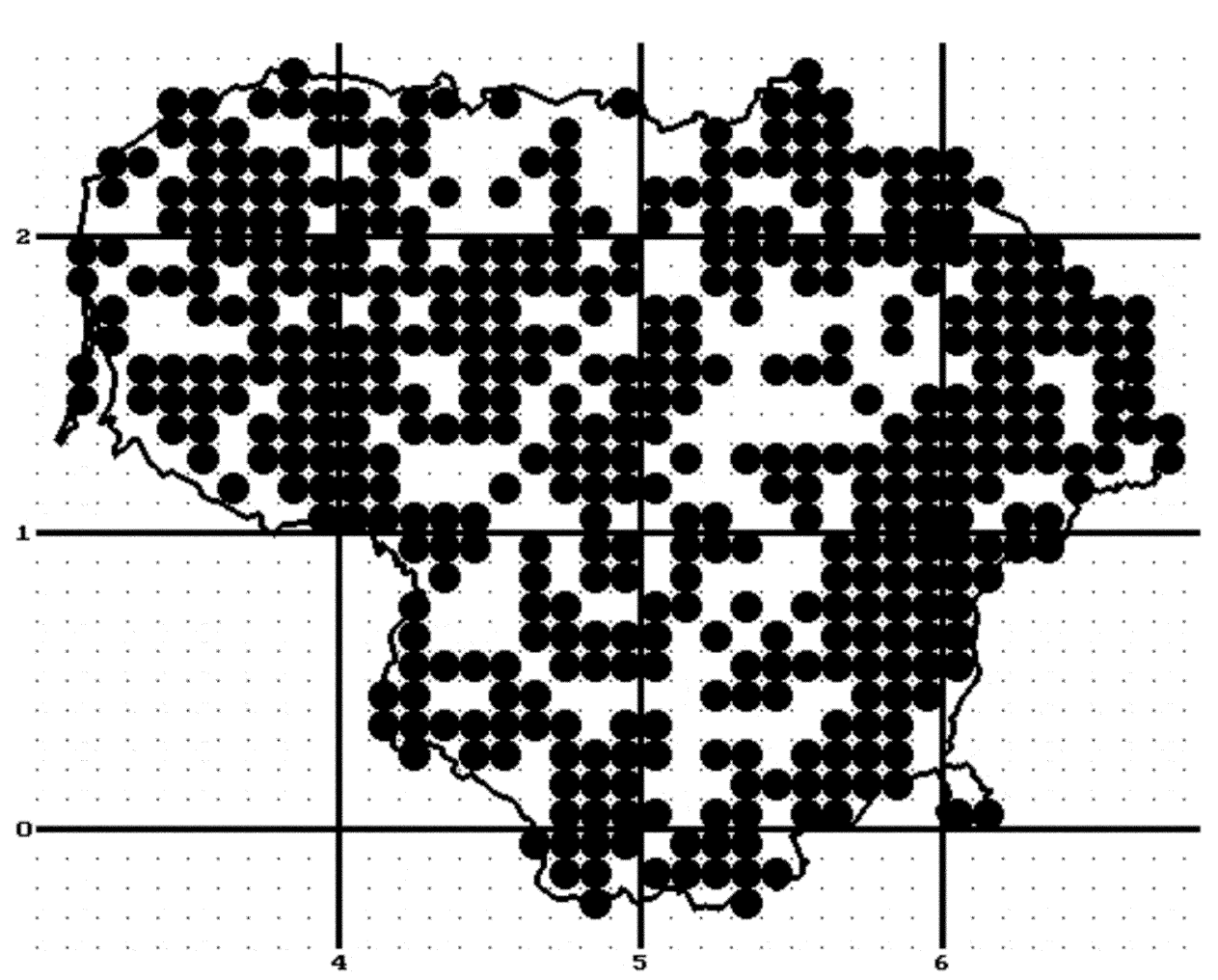

Fig. 1. Otter distribution in Lithuania in 1997-1999 (Balčiauskas et al., 1999).

trees, cavities in the shores, etc. (Balčiauskas et al., 1999). A positive influence of the presence of beavers (beaver ponds, burrows, and houses) was established. It was also found that the official survey numbers (1730 otters in 1997) were underestimated.

More than 10 years have passed from the last wide study on the otter distribution in Lithuania (Baranauskas et al., 1994; Balčiauskas et al., 1999). Moreover, the otter's national survey should be repeated at least every 10 years in order to get information about changes in its distribution and relative abundance. In protected areas, in order to build up baseline data, it is recommended to carry out surveys annually for the first five years and then at three-year intervals (Chanin, 2003).

The aim of this study was to examine the distribution of the otter in Lithuania, concentrating on types of water bodies and surrounding habitats.

\section{METHODS}

For studying the otter distribution, we used the so-called standard otter monitoring methods with some minor modification adapted to Lithuania (Reuther et al., 2000; 
Breaux et al., 2002; Elmeros \& Bussenius, 2002; Chanin, 2003; Strachan, 2007). The major part of data was collected in 2008 (681 sites), results from 2007 (64 sites) were also included. Data on the otter distribution were collected routinely by visiting various water bodies, including large and medium-sized rivers, streams and rivulets, lakes, artificial reservoirs (dammed rivers, ponds), as well as land reclamation ditches and fish farms. Rivers were classified as rivulets (length up to $10 \mathrm{~km}$ ), streams (10.1-50 km), medium-sized (50.1-200 km), and large ones (over $200 \mathrm{~km}$ ). With the help of maps (at least 1:50 000), potential sites were recorded trying to cover the whole area of Lithuania. Surveys were carried out in June-October when the water level was least variable. Surveys were not performed during heavy rain; five days without rain was an ideal period for surveys. In every site, all signs of otter presence were surveyed. The most suitable places - stones, fallen trees, sandy or muddy banks - were examined. The maximal length of the transect was $600 \mathrm{~m}$, but a survey was usually stopped as soon as otter signs were found. A special recording form was prepared for the survey, which included habitat description (water body parameters, environment characteristics within $100 \mathrm{~m}$ from water and bank characteristics within $20 \mathrm{~m}$ from water, anthropogenic disturbance, presence and number of the otter signs, presence of the American mink Mustela vison, and presence of other mammal species (Table 1). This method was fully compatible with the one we recommended for the state otter monitoring programme in 2008 .

Table 1. Parameters used in the form for the otter distribution survey

\begin{tabular}{|c|c|}
\hline Parameter & Description \\
\hline General information & $\begin{array}{l}\text { Date, surveyor's name, identification code, coordinates, } \\
\text { water body name, survey only under bridge } \\
\text { (yes/no), one bank/both banks, distance walked }\end{array}$ \\
\hline Watercourse/lake water level & Regulated, partial regulation, natural \\
\hline Water body parameters & $\begin{array}{l}\text { Width, depth, presence of beavers (dams, other signs } \\
\text { of their presence) }\end{array}$ \\
\hline $\begin{array}{l}\text { Environment characteristics within } \\
100 \mathrm{~m} \text { from water }\end{array}$ & $\begin{array}{l}\text { Meadows, arable land, forest, single farmsteads, } \\
\text { anthropogenic landscape (village, town), others } \\
\text { (fish ponds, reeds Phragmites australis) }\end{array}$ \\
\hline $\begin{array}{l}\text { Bank characteristics within } 20 \mathrm{~m} \\
\text { from water }\end{array}$ & $\begin{array}{l}\text { Grass vegetation, single trees, groups of trees or } \\
\text { shrubs, forest, oxbow } \\
\text { Dry habitat/wet habitat }\end{array}$ \\
\hline Anthropogenic disturbance & $\begin{array}{l}\text { Human activity: absent, insignificant, intensive } \\
\text { Motor boats: absent, occasionally, permanently }\end{array}$ \\
\hline Otter activity & $\begin{array}{l}\text { Scats (fresh, dried intact, dried fragmented) and their } \\
\text { number, latrines, footprints, jellies, food remains }\end{array}$ \\
\hline American mink activity & Scats number, footprints \\
\hline Other mammals' activity & Presence of any mammal species \\
\hline
\end{tabular}




\section{RESULTS AND DISCUSSION}

We checked 745 sites in various water bodies in 2007-2008. Out of them, 584 (78.4 \%) were found positive (Fig. 2).

From the water bodies investigated, various rivers constituted $79.2 \%$, reclamation ditches $5.9 \%$, lakes $11.6 \%$, artificial reservoirs $1.3 \%$, and fish farms $2.0 \%$. Fish farms were the most intensively used habitat - otters were found in all surveyed farms. This habitat provides the predator with unlimited and easily available food resources. Otters are abundant in this habitat and sometimes could make significant damage to fish farming, but in some cases damages are not serious (Ludwig et al., 2002; Kloskowski, 2005; Romanowski, 2006; Freitas et al., 2007). Other water bodies were also frequently used, especially artificial reservoirs, medium-sized rivers, and streams. Only reclamation ditches were not visited by otters so intensively (Fig. 3). The number of positive sites in all types of rivers and lakes was significantly higher than in reclamation ditches $\left(\chi^{2}=4.75-27.86, p=0.0294-0.0000\right)$. Lower abundance of otters in smallest rivers and reclamation ditches is typical (Sidorovich et al., 1996; Sidorovich, 1997; Romanowski, 2006). Otters were more frequently found in rivers $(82.4 \%$ positive sites) in comparison with lakes $\left(\chi^{2}=9.21, p=0.0024\right)$. The same tendency in otter densities in the mentioned habitats was also found in Belarus and Finland (Sidorovich, 1997; Sulkava, 2006; Sulkava \& Liukko, 2007). Comparison of the distribution in river groups with lakes revealed that only medium-sized rivers and streams were visited significantly more frequently than lakes $\left(\chi^{2}=10.22, p=0.0014\right.$

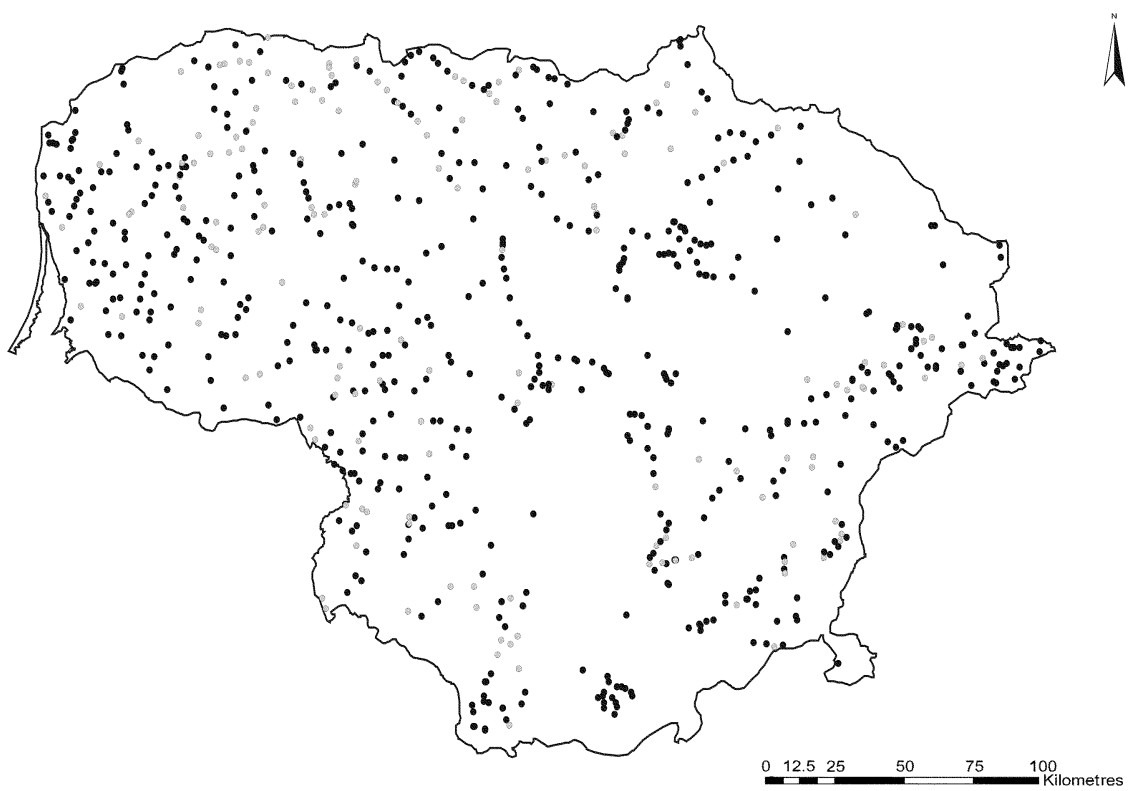

Fig. 2. Otter distribution in Lithuania in 2007-2008 (black circles - positive sites, grey circles negative sites). 
L. Baltrūnaitè et al.

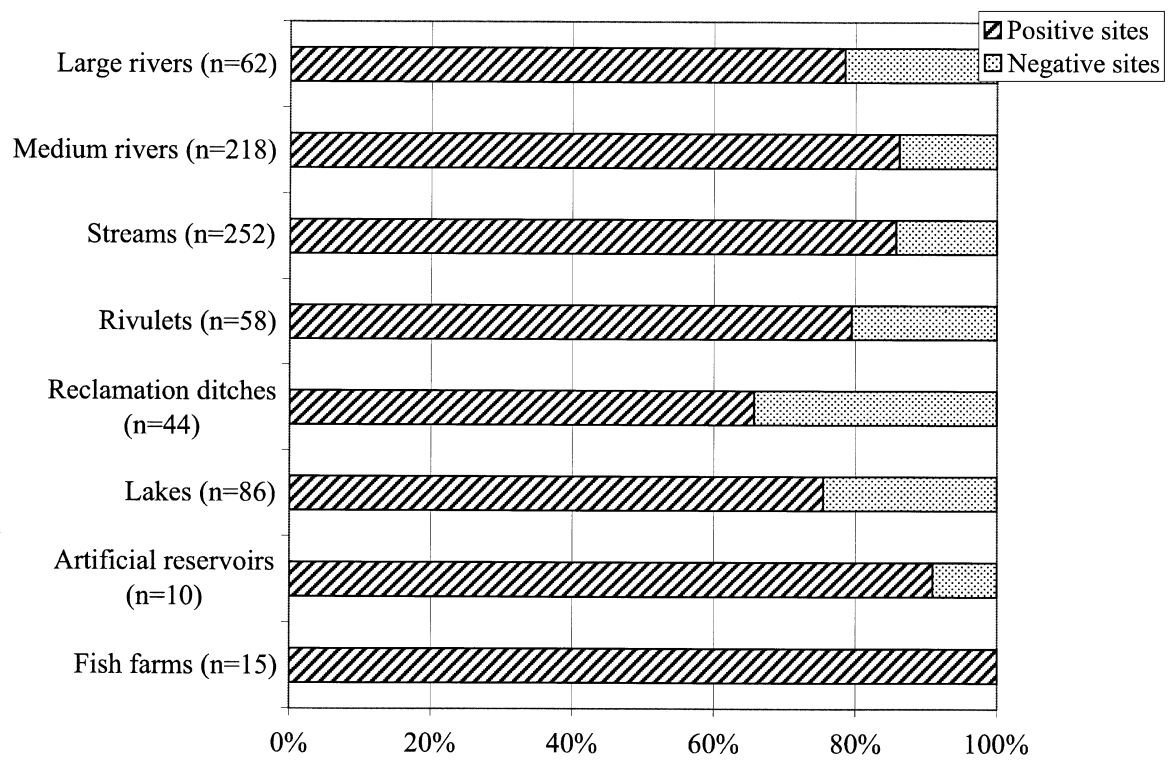

Fig. 3. Otter distribution in various water bodies in Lithuania.

and $\chi^{2}=9.86, p=0.0017$, respectively). However, it does not necessarily mean that rivers are a more favourable habitat for otters than lakes. The lower number of positive sites in lakes could be related to the fact that we usually checked rivers in especially favourable places for otters, for example, under the bridges, while in lakes the choice of the transect was random and it is possible that we missed marking places. This suggestion is confirmed by studies from Finland, where places near lakes - outflows and inflows of rivers - are most intensively used (Sulkava, 2006; Sulkava et al., 2007). So, in our opinion, the real number of positive sites in lakes should be higher than estimated.

Out of all studied water bodies, $475(63.8 \%)$ sites were natural, $68(9.1 \%)$ were indicated as partially regulated, and $202(27.1 \%)$ as regulated (water level or watercourse). Otters were found in $79.8 \%, 79.4 \%$, and $74.8 \%$ of the abovementioned sites, respectively. No significant difference in otter distribution was found among these groups. This fact showed that regulation of water bodies does not influence the presence of otters in Lithuania. However, Baranauskas \& Mickevičius (1995b) noted a positive correlation between the number of otter activity signs and the naturality of the river bed. This contradiction between results from studies in Lithuania could be related to differences in methods, small studied area and number of sites in Baranauskas \& Mickevičius (1995b).

Meadows, forests, and mixed habitat of meadows-forests predominated in the environs within $100 \mathrm{~m}$ of investigated water bodies (Table 2). Comparison of pure meadow habitat with mixed habitats of meadows-all other habitats, pure forest with mixed forest-other habitats as well as pure habitats-mixed habitats (in all cases not including anthropogenic landscape) did not show any significant 
Otter distribution in Lithuania

Table 2. Environment characteristics within $100 \mathrm{~m}$ from water (presence of certain habitat types)

\begin{tabular}{l|r|r|c}
\hline \multirow{2}{*}{ Habitat } & \multicolumn{2}{|c|}{ Sites } & $\begin{array}{c}\text { Number of positive } \\
\text { sites in the habitat, } \\
\%\end{array}$ \\
\cline { 2 - 3 } & Number & $\%$ & 78.7 \\
\hline Meadows & 108 & 14.5 & 80.8 \\
Forest & 104 & 14.0 & 58.3 \\
Arable land & 12 & 1.6 & 100.0 \\
Fish ponds & 15 & 2.0 & 73.3 \\
Anthropogenic landscape & 30 & 4.0 & 83.5 \\
Meadows-forest & 85 & 11.4 & 80.3 \\
Meadows-farmsteads & 71 & 9.5 & 80.3 \\
Meadows-arable land & 66 & 8.9 & 78.3 \\
Meadows-arable land-farmsteads & 60 & 8.1 & 83.7 \\
Meadows-forest-farmsteads & 49 & 6.6 & 64.5 \\
Meadows-anthropogenic landscape & 31 & 4.2 & 70.4 \\
Meadows-forest-arable land & 27 & 3.6 & 85.0 \\
Forest-farmsteads & 20 & 2.7 & 58.8 \\
Meadows-anthropogenic landscape-arable land & 17 & 2.3 & 69.2 \\
Farmsteads-arable land & 13 & 1.7 & 70.0 \\
Meadows-forest-arable land-farmsteads & 10 & 1.3 & 87.5 \\
Anthropogenic landscape-forests & 8 & 1.1 & 50.0 \\
Forest-arable land & 6 & 0.8 & 66.7 \\
Meadows-forest-anthropogenic landscape & 6 & 0.8 & 100.0 \\
Meadows-reeds & 2 & 0.3 & 100.0 \\
Farmsteads-forest-arable land & 2 & 0.3 & 100.0 \\
Anthropogenic landscape-arable land & 2 & 0.3 & 0.0 \\
Forest-reeds & 1 & 0.1 &
\end{tabular}

differences for otter presence. Thus, fragmentation or higher diversity of habitats do not affect otters' distribution. No significant differences were found for otter presence comparing forest, meadows, and arable land within $100 \mathrm{~m}$ of the investigated water bodies (neither each habitat nor meadows-arable land versus forest). Thus, wooded habitats did not increase the number of positive sites. Baranauskas \& Mickevičius (1995b), on the contrary, noted a positive correlation between wooded area and presence of otters (possible reasons of disagreement are again differences in methods, small studied area and number of sites). However, comparison of habitats that included anthropogenic landscape with all the other habitats revealed significant differences $\left(\chi^{2}=5.42, p=0.0199\right)$ : presence of villages or towns negatively influenced otters' presence. In anthropogenic landscapes many negative factors occur, e.g. human activity, traffic, dogs, etc. However, presence of single farmsteads did not influence the distribution of otters: no significant differences were found either when comparing habitats with farmsteads versus other habitats (excluding anthropogenic landscape), or even farmsteads-anthropogenic landscape versus all other habitats. So, low human disturbance is not a significant factor in the otter distribution. Several earlier studies also indicated otter's tolerance to human activity (Kemenes \& Demeter, 1995; Barbosa et al., 2001). 
Within $20 \mathrm{~m}$ from the shoreline, mixed habitats of grass vegetation-groups of trees and grass vegetation-forest were most frequent (Table 3). Comparison of otter presence in various pure habitats with fragmented ones or grass vegetation with all other habitats did not show any significant difference. Probably, bank vegetation is not important for otters and their presence or absence is determined by availability of suitable places for marking, e.g. sandy banks, stones, fallen trees.

Importance of surrounded habitats has been studied by many authors with different results obtained. Some studies revealed a positive influence of more wooded land for otter presence (Lodé, 1993; Baranauskas \& Mickevičius, 1995b). Kemenes \& Demeter (1995) found a positive effect of land cultivation around the aquatic habitats. Still, others indicated no difference in the proportion of positive sites according to shore type or terrestrial habitats (Durbin, 1998; McMahon \& McCafferty, 2006) and our results coincide with the latter. Barbosa et al. (2001) found environmental factors to have more influence on otter presence than human ones. Food supply was also indicated as one of the most important factors for otter presence (Prenda \& Granado-Lorencio, 1996; White et al., 2003). Probably, there is a complex of factors that determine otter distribution (e.g. food supply, physical characteristics of the river, human disturbance, riparian vegetation) and their importance differs in various study sites (Ottino et al., 1995; Prenda \& Granado-Lorencio, 1996; Durbin, 1998; White et al., 2003; Ottino \& Giller, 2004).

In 1999, otter was a widespread and fairly common species (Fig. 1) inhabiting various water bodies in Lithuania (Balčiauskas et al., 1999). Fast flowing mediumsized and small rivers were indicated as the most favourable.

Our results of otter distribution were similar to previous findings (Balčiauskas et al., 1999). Namely, the predator is widely distributed across the country. The most intensively used habitats could be divided into two groups: artificial habitats (fish farms and artificial reservoirs) and natural ones (medium-sized rivers and streams). Otters were also found in almost half of the least visited reclamation ditches. Usually, otters use various water bodies when the species is abundant, and when abundance decreases, the predator is more specific in its choice of

Table 3. Environment characteristics within $20 \mathrm{~m}$ from water (presence of certain habitat types)

\begin{tabular}{|c|c|c|c|}
\hline \multirow[t]{2}{*}{ Habitat } & \multicolumn{2}{|c|}{ Sites } & \multirow{2}{*}{$\begin{array}{c}\text { Number of positive } \\
\text { sites in the habitat, } \\
\%\end{array}$} \\
\hline & Number & $\%$ & \\
\hline Grass vegetation & 85 & 11.4 & 75.3 \\
\hline Forest & 14 & 1.9 & 78.6 \\
\hline Groups of trees & 10 & 1.3 & 80.0 \\
\hline Grass vegetation-groups of trees & 254 & 34.1 & 79.5 \\
\hline Grass vegetation-forest & 142 & 19.1 & 83.8 \\
\hline Grass vegetation-single trees-groups of trees & 94 & 12.6 & 71.3 \\
\hline Grass vegetation-single trees & 64 & 8.6 & 82.8 \\
\hline Grass vegetation-groups of trees-forest & 64 & 8.6 & 73.4 \\
\hline Grass vegetation-single trees-groups of trees-forest & 11 & 1.5 & 54.5 \\
\hline Grass vegetation-single trees-forest & 7 & 0.9 & 100.0 \\
\hline
\end{tabular}


Otter distribution in Lithuania

habitats (Sidorovich, 1997; Romanowski, 2006). Thus, the wide distribution of otters in various habitats suggested that the state of the otter population in Lithuania is good.

\section{ACKNOWLEDGEMENTS}

We thank Dr Risto Sulkava for valuable comments on the manuscript. The study was supported by The Ministry of Environment of the Republic of Lithuania.

\section{REFERENCES}

Balčiauskas, L., Trakimas, G., Juškaitis, R., Ulevičius, A. \& Balčiauskienė, L. 1997. Atlas of Mammals, Amphibians and Reptiles in Lithuania. Akstis, Vilnius (in Lithuanian).

Balčiauskas, L., Trakimas, G., Juškaitis, R., Ulevičius, A. \& Balčiauskienè, L. 1999. Atlas of Mammals, Amphibians and Reptiles in Lithuania. Second edition. Akstis, Vilnius (in Lithuanian).

Baranauskas, K. \& Mickevičius, E. 1995a. The new data on the otter in Lithuania. Lutreola, 5, 11-14.

Baranauskas, K. \& Mickevičius, E. 1995b. Some factors influencing the habitat use by otter (Lutra lutra) in Vilnius region. Ekologija, 2, 49-53.

Baranauskas, K., Mickevičius, E., Macdonald, S. M. \& Mason, C. F. 1994. Otter distribution in Lithuania. Oryx, 28(2), 128-130.

Barbosa, A. M., Real, R. \& Marquez, A. L. 2001. Spatial, environmental and human influences on the distribution of otter (Lutra lutra) in the Spanish provinces. Divers. Distrib., 7, 137-144.

Breaux, A., Zielinski, W. \& Kucera, T. 2002. Data Collection Protocol Monitoring River Otter (Lutra [= Lontra] canadensis). Wetlands Regional Monitoring Program Plan 2002. Part 2: Data Collection Protocols. San Francisco Estuary Institute.

Chanin, P. 2003. Monitoring the Otter Lutra lutra. Conserving Natura 2000 Rivers Monitoring Series No. 10. English Nature, Peterborough.

Conroy, J. W. H. \& Chanin, P. 2001. The distribution and status of the European otter (Lutra lutra) - A review. In Proceedings of the Otter Toxicology Conference, Skye, 2000 (Conroy, J. W. H., Gutleb, A. \& Yoxon, P., eds), pp. 7-28. International Otter Survival Fund, Broadford, Skye.

Durbin, L. S. 1998. Habitat selection by five otters Lutra lutra in rivers of northern Scotland. J. Zool., 245, 85-92.

Elmeros, M. \& Bussenius, N. 2002. Influence of selection of bank side on the standard method for otter surveys. IUCN Otter Specialist Group Bull., 19, 67-74.

Freitas, D., Gomes, J., Sales Luis, T., Marques, L. M. C., Baptista, G., Rosalino, L. M., Antunes, P., Santos, R. \& Santos-Reis, M. 2007. Otters and fish farms in the Sado estuary: ecological and socio-economic basis of a conflict. Hydrobiologia, 587, 51-62.

Kemenes, I. \& Demeter, A. 1995. A predictive model of the effect of environmental factors on the occurrence of otters (Lutra lutra L.) in Hungary. Hystrix, 7(1-2), 209-218.

Kloskowski, J. 2005. Otter Lutra lutra damage at farmed fisheries in southeastern Poland, I: an interview survey. Wildlife Biol., 11, 201-206.

Lodé, Th. 1993. The decline of otter Lutra lutra populations in the region of the Pays de Loire, Western France. Biol. Conserv., 65, 9-13.

Ludwig, G. X., Hokka, V., Sulkava, R. \& Ylönen, H. 2002. Otter Lutra lutra predation on farmed and free-living salmonids in boreal freshwater habitats. Wildl. Biol., 8, 193-199.

McMahon, J. \& McCafferty, D. J. 2006. Distribution and diet of otters (Lutra lutra) in marine areas of Loch Lomond and the Trossachs National Park, Scotland, UK. Lutra, 49(1), 29-36.

Mickevičius, E. 1993. The otter in Lithuania. IUCN Otter Specialist Group Bull., 8, 29-31. 
L. Baltrūnaitė et al.

Ottino, P. \& Giller, P. 2004. Distribution, density, diet and habitat use of the otter in relation to land use in the Araglin Valley, southern Ireland. Biol. Environ. Proc. Roy. Irish Acad., 104B(1), $1-17$.

Ottino, P., Prigioni, C. \& Vigna Taglianti, A. 1995. Habitat suitability for the otter (Lutra lutra) of some rivers of Abruzo Region (Central Italy). Hystrix, 7(1-2), 265-268.

Prenda, J. \& Granado-Lorencio, C. 1996. The relative influence of riparian habitat structure and fish availability on otter Lutra lutra L. sprainting activity in a small Mediterranean catchment. Biol. Conserv., 76(1), 9-15.

Reuther, C., Dolch, D., Green, R., Jahrl, J., Jefferies, D., Krekemeyer, A., Kucerova, M., Madsen, A. B., Romanowski, J., Roche, K., Ruiz-Olmo, J., Teubner, J. \& Trindade, A. 2000. Surveying and monitoring distribution and population trends of the Eurasian otter (Lutra lutra). Habitat, 12, $1-148$

Romanowski, J. 2006. Monitoring of the otter recolonization of Poland. Hystrix, 17(1), 37-46.

Sidorovich, V. E. 1997. Mustelids in Belarus. Zolotoj Uleij, Minsk (in Russian).

Sidorovich, V. E., Jędrzejewska, B. \& Jędrzejewski, W. 1996. Winter distribution and abundance of mustelids and beavers in the river valleys of Białowieza Primeval Forest. Acta Theriol., 41(2), 155-170.

Strachan, R. 2007. National Survey of Otter Lutra lutra Distribution in Scotland 2003-2004. Scottish Natural Heritage Commissioned Report No. 211.

Sulkava, R. 2006. Ecology of the Otter (Lutra lutra) in Central Finland and Methods for Estimating the Densities of Population. PhD Dissertation, University of Joensuu.

Sulkava, R. \& Liukko, U.-M. 2007. Use of snow-tracking methods to estimate the abundance of otter (Lutra lutra) in Finland with evaluation of one-visit census for monitoring purposes. Ann. Zool. Fenn., 44, 179-188.

Sulkava, R. T., Sulkava, P. O. \& Sulkava, P. E. 2007. Source and sink dynamics of densitydependent otter (Lutra lutra) population in rivers of central Finland. Oecologia, 153, 579-588.

Ulevičius, A. \& Balčiauskas, L. 1994. Otter population density in Lithuania. In Seminar on the Conservation of the European Otter (Lutra lutra), pp. 77-79. Council of Europe, Leeuwarden, The Netherlands.

White, P. C. L., McClean, C. J. \& Woodroffe, G. L. 2003. Factors affecting the success of an otter (Lutra lutra) reinforcement programme, as identified by post-translocation monitoring. Biol. Conserv., 112, 363-371.

\title{
Saarma levik Leedus 2008. aastal ja selle muutus viimasel aastakümnel
}

\author{
Laima Baltrūnaitė, Linas Balčiauskas, Raimundas Matulaitis \\ ja Vitalijus Stirkè
}

Saarma levikut Leedus uuriti aastatel 2007-2008, kasutades selleks väljaheiteid ja muid tegevusjälgi (nn monitooringu standardmeetodid). Kokku uuriti 745 paika eri veekogudel: jõgedel, järvedel, kuivenduskraavidel, kalakasvatustiikidel ja tehisjärvedel. Positiivne tulemus saadi 584 (78,4\%) paigas. Kalakasvatustiigid olid enim kasutatavad elupaigad: saarmaid leiti kõikides uuritud kalakasvatusfarmides. Sagedasti olid asustatud ka tehisjärved, keskmise pikkusega jõed ja ojad. Leiti, et uuritud keskkonnateguritest avaldab saarma esinemisele mõju ainult antropogeenne maastik, kui see ulatub veeservale lähemale kui 100 m. Järeldati, et saarma asurkonna seis Leedus on hea: loomad on laialt levinud ja asustavad erinevat tüüpi veekogusid. 